\title{
IAMJ
}

INTERNATIONAL

AYURVEDIC

MEDICAL JOURNAL

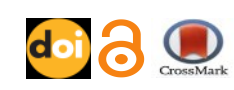

\section{MANAGEMENT OF MIGRAINE THROUGH PANCHKARMA - A CASE STUDY}

\section{$\underline{\text { Sunita }}^{1}, \underline{\text { Aakanksha Sharma }}^{2}, \underline{\text { Mahesh Kumar Sharma }}^{3}$, $\underline{\text { Gyan Prakash Sharma }}^{4}$}

${ }^{1}$ P.G. Scholar, PG Department of Panchkarma, Dr. S. R. Rajasthan Ayurved University, Nagaur Highway Road, Karwar, Jodhpur, Rajasthan, India

${ }^{2}$ P.G. Scholar, PG Department of Swasthvritta \& Yoga, Dr. S. R. Rajasthan Ayurved University, Nagaur Highway Road, Karwar, Jodhpur, Rajasthan, India

${ }^{3}$ M.D. (Ayu). Professor \& Head of Panchkarma Department Dr. S. R. Rajasthan Ayurved University, Nagaur Highway Road, Karwar, Jodhpur, Rajasthan, Rajasthan, India

${ }^{4}$ M.D. (Panchkarma) Associate Professor of Panchkarma Department Dr. S. R. Rajasthan Ayurved University, Nagaur Highway Road, Karwar, Jodhpur, Rajasthan, India

Corresponding Author: sunitaprajapat721@gmail.com

\section{https://doi.org/10.46607/iamj3909042021}

(Published online: April 2021)

Open Access

(C) International Ayurvedic Medical Journal, India 2021

Article Received: 25/03/2021 - Peer Reviewed: 30/03/2021 - Accepted for Publication: 31/03/2021

\section{Check for updates}

\begin{abstract}
Ardhavabhedaka is a type of Shiroroga. It is an episodic, painful, disabling and unilateral headache with Complications of blindness and hearing loss. It can be clinically correlated with migraine based on clinical manifestation. Affecting at least 1 adult in every 7 in the world (WHO). It is 3 time more common in women than men. it causes moderate to severe pain that is throbbing or pulsating, requiring long-term management. It causes personal suffering, impaired quality of life and high financial cost. Nasya Karma and Shirodhara are the prime treatment modalities for Shirogata disease. A 19-year-old girl patient came OPD with complaining of severe headache. Shirodhara done with milk + Dashmool-Kwath and Mahanarayan tail. After done this Panchkarma treatment patient got highly significant relief in the cardinal symptoms of Ardhavabhedaka.
\end{abstract}

Keywords: Migraine, Ardhavbhaedaka, Shirodhara 


\section{INTRODUCTION}

Migraine is the second most prevalent brain disorder after anxiety, affecting nearly 41 million adult ${ }^{1}$. Comorbidity with migraine is associated with more severe depression, anxiety and somatic symptoms, as well as a poor health related quality of life $\mathrm{f}^{2,3,4}$. About 3000 cases of migraine occur every day for each millions of population 5. Migraine can be closely related to Ardhavbhedak due to its cardinal feature "half side headache "which is also explained by Chakrapani as "Ardhamastakvedana". The word Ardhavbhedak means half side perforating or breaking like pain. Acharya Charak has explained it as pure Vataj or Vatkaphaj ${ }^{7}$. Weather, missing a meal, stress, alcohol, allergic reaction, loud noise, certain odors, computer or mobile screen and certain types of food are trigger factor of migraine. Menstrual period is a trigger factor in $50 \%$ women. The modern drugs are not acceptable due to their drawback, dependency, withdrawal syndrome, relapse of headache within hours and getting chronic headache. In Ayurveda textbook Shirodhara therapy and Nasya is considered chief treatment for Shirogat roga.

\section{CASE REPORT}

A 19 years old, unmarried girl came in IPD of Panchakarma Department on date 12 /11/2019 with complaints of severe bilateral temporal severe headache, on and off twice in a day with scalp tenderness, anxiety during headache and stress since 2 years and got admitted in IPD of Panchakarma Department, Dr SR
Rajasthan Ayurvedic University Jodhpur. OPD no43119 and IPD no-

\section{Clinical Findings}

Patient complains of severe bilateral temporal headache and scalp tenderness and feeling anxiety during headache since 2 years. Once headache start than it persists 3 hours about. She got headache without aura in early morning just after wakeup, after work related stress, after travelling, after long distance walking and in hot environment. Although she feels relax from headache after sleeping and in evening time. No significant personal and family history identified. After $D a$ savidha Pareeksha it is found that patient have Vata Prakriti with Avar-Sara, Sanhanana, Pramana, Aharashakti, and Vyayama Shakti. She has AvaraSatwa.

\section{Samprapti}

According to Accharya Charak, Atialp- bhojan, Ruksh -bhojan, Vegdharan, Ativyayama, Ratrijagaran and Sheet Vayu Sevan Vata either individually or with vitiated Kapha gets lodged in half portion of the head causes Teevra Vedana. According to Aacharya Videha, the Vata aggravated in any one side of the head on getting blocked by morbid kaph causes headache. The episodes of headache occur once in $3,5,15$ or 30 days.

\section{Samprapti Ghatak}

Sharirika Dosha-Vata or Vata-Kapah, Dusya - Ras and Rkta-Dhatu, Adhisthana- Shiropradesh, Agnimandy, Srotas- Rasvaha and Raktavaha, Sadhya Asadhyata- Kricchrasadhya

\section{Interventional Schedule:}

\begin{tabular}{|l|l|l|l|}
\hline Karm & Material & Duration & days \\
\hline Shirodhara & Dashmool kwath with milk & $40 \mathrm{~min}$ & 3 days \\
\hline Shirodhara & Mahanarayan oil and til tail & $40 \mathrm{~min}$ & 7 days \\
\hline
\end{tabular}

Updrava-deafness and blindness

\section{DISCUSSION}

Ardhavbhedak is vaat and Vaat- Kapha Pradhan Shirorog, it symptoms and Nidana mentioned in our samhitas are similar with migraine symptoms and causes. Tension, Missing meals, poor diet are the causative factors for Migraine. The process in which gently pouring liquids on the forehead about 4-inch hight called Shirodhara. The liquids used in Shirodhara can include oil, milk, buttermilk, coconut water or even plain water. Its work by relaxing the hypothalamus in the brain by vibration and also normalize the functions of hormones. 
The soothing of Marmas and in turn soothing of Nervous system and endocrine glands in the brain ${ }^{8}$.

\section{CONCLUSION}

There was significant improvement in the symptoms of migraine, On the basis of this case study, Shirodhara with Dashamula Kwatha + Kshira and Nasya with Anu tail are good option for management of migraine.

\section{REFERENCES}

1. Stovner L J, Hagen K: Prevalence, burden, and cost of headache disorders. Cur-rent Opinion in Neurology 2006, 19(3):281-285.

2. Hung CI, Liu CY, Juang YY et al (2006) The impact of migraine on patients with major depressive disorder. Headache 46:469-477

3. Hung CI, Wang SJ, Yang CH et al (2008) The impacts of migraine, anxiety disorders, and chronic depression on quality of life in psychiatric outpatients with major depressive disorder. J Psychosom Res 65:135-142

4. Oedegaard KJ, Fasmer OB (2005) Is migraine in unipolar depressed patients a bipolar spectrum trait? J Affect Disord 84:233-242

5. Headache Disorders Fact Sheet No. 277. http://www.who.int/mediacentre/factsheets /fs277/en/ assessed on $25 / 08 / 2017$

6. (Choudhary Bhanu Priya Et Al: Role of Ayurveda In Management Of Ardhavabhedaka (Migraine). International Ayurvedic Medical Journal \{online\} 2017 \{cited March,2017\} Available from: http://www.iamj .in/posts/images/upload/985- 990.pdf

7. Santosh S. Pujari, Veerayya Hiremath. A Comparative clinical Study on Sharkara Mishrita Dugda Nasya and Murchita Ghrita Nasya on Ardhavabhedaka w.s.r. to Migraine; AYUSHDHARA, 2016;4(3):1159-1164

8. Bhageshwary Janagal et al: A Conceptual Study of Shirodhara in the management of Shirashoola; AYUSHDHARA,2017;4(1):1045-1050,

https://ayushdhara.in

\section{Source of Support: Nil}

\section{Conflict of Interest: None Declared}

How to cite this URL: Sunita et al: Management Of Migraine Through Panchkarma Treatment - A Case Study. International Ayurvedic Medical Journal \{online\} 2021 \{cited April, 2021\} Available from: http://www.iamj.in/posts/images/upload/913 915.pdf 